\title{
PENGOMPOSAN ECENG GONDOK (Eichornia Crassipes SOLMS) DENGAN METODE SEMI ANAEROB DAN PENAMBAHAN AKTIVATOR EM4
}

\author{
Marjenah $^{1}$ dan Justina Simbolon ${ }^{2}$ \\ ${ }^{1,2}$ Laboratorium Silvikultur Fakultas Kehutanan Universitas Mulawarman \\ Gedung B11 Lantai 2 Kampus Gunung Kelua Jl. Penajam SAMARINDA 75119 \\ E-mail Korespondensi: marjenah_umar@yahoo.com
}

\begin{abstract}
ABSTRAK
Pengomposan Eceng gondok (Eichornia Crassipes SOLMS) Dengan Metode Semi Anaerob dan Penambahan Aktivator EM4.

Eceng gondok (Eichornia Crassipes) adalah tumbuhan yang tumbuh di perairan seperti danau, sungai dan rawa-rawa. Eceng gondok dapat dimanfaatkan sebagai pupuk organik yang terlebih dahulu harus dikomposkan. Kompos eceng gondok tidak hanya dapat membantu memenuhi kebutuhan unsur hara bagi tanaman, tetapi dapat membantu memperbaiki sifat fisik tanah. Penelitian ini bertujuan untuk mengetahui kandungan unsur hara di dalam kompos eceng gondok dan memanfaatkan tanaman eceng gondok sebagai alternatif pembuatan kompos untuk media tumbuh tanaman di persemaian serta mengetahui efisiensi penggunaan aktivator EM4 pada proses pengomposan eceng gondok. Pembuatan kompos eceng gondok dengan metode semi anaerob menggunakan aktivator EM4 dilakukan dengan tujuan mempercepat penguraian bahan organik menjadi kompos. Proses pengomposan dilakukan selama 21 hari dan menghasilkan kompos jadi sebanyak $25,4 \mathrm{~kg}$ $(17,15 \%)$ dengan parameter yang diamati meliputi warna, bau, suhu, kelembaban, $\mathrm{pH}$, kadar unsur hara $\mathrm{N}, \mathrm{P}$, $\mathrm{K}, \mathrm{Ca}, \mathrm{Mg}$ dan kadar C-Organik serta $\mathrm{C} / \mathrm{N}$ bahan. Hasil analisis kualitas kimia kompos yang dihasilkan dari kompos eceng gondok dengan metode semi anaerob menggunakan aktivator EM4, untuk suhu rata-rata $=42,1$ ${ }^{\circ} \mathrm{C}$, Kadar unsur hara $\mathrm{N}=2,00 \%, \mathrm{P}=0,582 \%, \mathrm{~K}=1,87 \%, \mathrm{CaO}=2,358 \%, \mathrm{MgO}=0,390 \%$, Kadar $\mathrm{C}$ - Organik $=19,29 \%$ memenuhi Standar SNI 19-7030-2004 kecuali $\mathrm{pH}=$ 7,82 melebihi standar.
\end{abstract}

Kata kunci: Aktivator EM4, eceng gondok, kompos, konsentrasi unsur hara.

\begin{abstract}
Composting of Water hyacinth (Eichornia Crassipes SOLMS) with Semi Anaerobic Method and Addition of EM4 Activator.

Eichornia crassipes is a plant that grows on on the water such as lakes, rivers and swamps. E. crassipes can be used as organic fertilizer that must first be composted E. crassipes compost not only can help fulfill nutrient needs for the plant, but it also can help improve the physical properties of the soil. This study aims to determine the nutrient content of E. crassipes compost and utilize that plants as an alternative to growing media composting plants in the nursery as well as determine the efficiency of the use of activators EM4 on the composting process of E. Crassipes. Composting E. crassipes with semi-anaerobic method using EM4 activator is done with the aim of accelerating the decomposition of organic material into compost. The composting process was conducted for 21 days and produce a finished compost as much as $25.4 \mathrm{~kg}(17.15 \%)$ with the observed parameters include color, odor, temperature, humidity, $p H$, concentration of nutrients $N, P$, $K, \mathrm{Ca}, \mathrm{Mg}$ and levels Organic $C$ and $C / N$ material. The results of the analysis of the chemical quality of the compost produced from water hyacinth compost with semi-anaerobic method using EM4 activator, for the average temperature $=42.1^{\circ} \mathrm{C}$, levels of nutrients $\mathrm{N}=2.00 \%, \mathrm{P}=0.582 \%, \mathrm{~K}=1.87 \%, \mathrm{CaO}=2,358 \%, \mathrm{MgO}$ $=0.390 \%$, levels of $C-$ Organic $=19.29 \%$ fulfill the standard of SNI 19-7030-2004 except pH $=7.82$ higher than standard.
\end{abstract}

Key words: Eichornia crassipes, EM4 activator, compost, concentration of nutrient. 


\section{PENDAHULUAN}

Bahan organik memiliki peran penting dalam menentukan kemampuan tanah untuk mendukung pertumbuhan tanaman, sehingga jika kadar bahan organik tanah menurun, kemampuan tanah dalam mendukung produktivitas tanaman juga menurun. Menurunnya kadar bahan organik merupakan salah satu bentuk kerusakan tanah yang umum terjadi. Kerusakan tanah merupakan masalah penting bagi pertumbuhan tanaman.

Kerusakan tanah secara garis besar dapat digolongkan menjadi tiga kelompok utama, yaitu kerusakan sifat kimia, fisika dan biologi tanah. Kerusakan kimia tanah dapat terjadi karena proses pemasaman tanah, akumulasi garam-garam (salinisasi), tercemar logam berat, dan tercemar senyawa-senyawa organik seperti pestisida atau tumpahan minyak bumi. Terjadinya pemasaman tanah dapat diakibatkan penggunaan pupuk nitrogen buatan secara terus menerus dalam jumlah besar (Subroto dan Yusrani, 2005).

Kerusakan tanah secara fisik dapat diakibatkan karena kerusakan struktur tanah yang dapat menimbulkan pemadatan tanah. Kerusakan struktur tanah ini dapat terjadi akibat pengolahan tanah yang salah atau penggunaan pupuk kimia secara terus menerus. Kerusakan biologi ditandai oleh penyusutan populasi maupun berkurangnya biodiversitas organisme tanah, dan terjadi biasanya bukan kerusakan sendiri, melainkan akibat dari kerusakan lain (fisik dan kimia).

Tanah-tanah yang sudah mengalami kerusakan akan sulit mendukung pertumbuhan tanaman. Sifat-sifat tanah yang sudah rusak memerlukan perbaikan agar tanaman dapat tumbuh dan berproduksi kembali secara optimal. Penyediaan hara bagi tanaman dapat dilakukan dengan penambahan pupuk, baik pupuk organik maupun pupuk anorganik. Pupuk anorganik dapat menyediakan hara dengan cepat. Namun apabila hal ini dilakukan terus menerus akan meningkatkan keasaman tanah, menimbulkan kerusakan pada tanah dan mengakibatkan ketersediaan hara dalam tanah semakin berkurang serta dapat mengurangi umur produktif tanaman. Hal ini tentu saja tidak menguntungkan bagi pertanian yang berkelanjutan (Suriany, 2007).

Pupuk organik merupakan hasil akhir dari penguraian bagian-bagian atau sisa-sisa serasah tanaman dan binatang misalnya pupuk kandang, pupuk hijau dan kompos. Pupuk organik memang memiliki berbagai keunggulan dibanding pupuk anorganik diantaranya pupuk organik dapat mengatur sifat tanah dan dapat berperan sebagai penyangga persediaan unsur hara bagi tanaman sehingga pupuk organik dapat mengembalikan kesuburan tanah. Pupuk organik juga mampu menggemburkan lapisan permukaan tanah (top soil), mempertinggi daya serap dan daya simpan air, yang oleh karenanya kesuburan tanah menjadi meningkat (Yuliarti, 2009).

Kompos adalah bahan-bahan organik (sampah organik) yang telah mengalami proses pelapukan karena adanya interaksi antara mikroorganisme (bakteri pembusuk) yang bekerja di dalamnya (Murbandono, 2003). Kompos mampu memberikan unsur hara bagi tanaman, kompos dapat memperbaiki sifat tanah yang rusak menjadi produktif dan dapat digunakan untuk meningkatkan kualitas dan kuantitas tanaman. Satu diantaranya bahan pembuatan kompos yaitu tumbuhan eceng gondok (Eichornia Crassipes).

Kompos bersifat hidrofilik sehingga dapat meningkatkan kemampuan tanah dalam memegang air dan mengandung unsur karbon yang relatif tinggi sehingga dapat menjadi sumber energi mikroba. Jumlah populasi mikroorganisme tanah akan meningkat akibat pemberian kompos. Aktivitas mikroba ini membantu 
tanaman untuk menyerap unsur hara dari tanah dan menghasilkan senyawa yang dapat merangsang pertumbuhan tanaman. Aktivitas mikroba tanah juga diketahui dapat membantu tanaman menghadapi serangan penyakit. Adanya cacing tanah dalam media penelitian mengindikasikan bahwa setelah mengalami pemupukan, tanah bersifat subur akibat kandungan unsur hara yang mencukupi. Adanya cacing tanah ikut membantu perbaikan serta meningkatkan kesuburan tanah (Setyaningsih 2007).

Eceng gondok (Eichornia Crassipes) adalah tumbuhan yang tumbuh di perairan seperti danau, sungai dan rawarawa, laju pertumbuhan dari tanaman ini sangat cepat sehingga dapat menutupi permukaan air yang dapat mengganggu kegiatan masyarakat di sekitar perairan. Eceng gondok tidak hanya memiliki dampak negatif akan tetapi eceng gondok juga memiliki dampak positif. Jumlah eceng gondok di setiap perairan ini sangat banyak tetapi masyarakat belum tahu bagaimana cara memanfaatkan tumbuhan ini, padahal tumbuhan eceng gondok dapat digunakan sebagai sumber pangan langsung untuk biofag-biofag air (pakan makhluk hidup), sebagai bahan pangan manusia, makanan ternak, sumber kerajinan tangan, sebagai pemurnian air dari pencemaran-pencemaran limbah pertanian, pencemaran organik, pencemaran limbah rumah tangga, dan menahan sistem drainase serta sebagai bahan baku pembuatan pupuk organik seperti kompos. Kompos eceng gondok tidak hanya dapat membantu memenuhi kebutuhan unsur hara bagi tanaman, tetapi dapat membantu memperbaiki sifat tanah, terutama bagi sifat kimia tanah (Hajama, 2014).

Samekto (2006) menyatakan bahwa kompos mampu mengurangi kepadatan tanah sehingga memudahkan perkembangan akar dan kemampuannya dalam penyerapan hara. Peranan bahan organik dalam pertumbuhan tanaman dapat mempengaruhi tanaman melalui perubahan sifat dan ciri tanah.

Pengomposan eceng gondok dengan metode aerob telah dilakukan oleh Fitriansyah (1997), dengan menggunakan beberapa perlakuan yaitu perlakuan tanpa penirisan, perlakuan tiga hari penirisan dan perlakuan enam hari penirisan sebelum pengomposan. Hasil terbaik yang diperoleh pada penelitian Fitriansyah (1997) tersebut adalah perlakuan enam hari penirisan sebelum pengomposan.

Tujuan penelitian pembuatan kompos eceng gondok dengan metode semi anaerob dan menggunakan aktivator EM4 serta untuk memanfaatkan eceng gondok yang selama ini dianggap mencemari lingkungan sebagai alternatif pembuatan kompos untuk media tumbuh tanaman di persemaian, mengetahui kandungan unsur hara yang terkandung di dalam kompos eceng gondok, dan mengetahui efisiensi penggunaan aktivator EM4 pada proses pengomposan eceng gondok.

\section{METODA PENELITIAN}

\subsection{Tempat dan Waktu}

Penelitian pembuatan kompos ini dilaksanakan di areal Persemaian Fakultas Kehutanan Universitas Mulawarman dan analisis kandungan hara kompos dilakukan di Laboratorium Tanah Fakultas Pertanian Universitas Mulawarman. Penelitian ini memerlukan waktu selama \pm 5 (lima) bulan efektif meliputi studi pustaka, orientasi lapangan, persiapan penelitian, pembuatan kompos, pengamatan (pengumpulan data), analisis data dan penulisan hasil penelitian.

\subsection{Bahan dan Alat}

Bahan yang digunakan dalam penelitian antara lain: 
1. Tumbuhan Eceng Gondok sebanyak $35 \mathrm{~kg}$.

2. Kotoran ayam sebanyak $21 \mathrm{~kg}$.

3. Arang sekam sebanyak $7 \mathrm{~kg}$.

4. Dedak halus sebanyak $7 \mathrm{~kg}$.

5. Gula pasir sebanyak $17,5 \mathrm{~g}$.

6. EM4 sebanyak $70 \mathrm{ml}$.

7. Air secukupnya.

Peralatan yang digunakan untuk penelitian antara lain:

1. Thermohygrometer, untuk mengukur suhu dan kelembapan.

2. Timbangan, untuk menimbang bahan-bahan kompos.

3. Terpal ukuran $4 \mathrm{~m} \times 4 \mathrm{~m}$, sebagai alas atau tempat pencampuran bahan dan menutup kompos selama proses fermentasi.

4. 4.Mesin pencacah, untuk menghaluskan bahan baku kompos

5. Kamera, untuk dokumentasi.

6. Pipa paralon dengan diameter $5 \mathrm{~cm}$ dengan panjang $50 \mathrm{~cm}$, untuk sirkulasi udara padaproses pengomposan.

7. Ember, untuk mengencerkan bahan pengurai kompos.

8. Gembor plastik, untuk menyiram bahan kompos yang sedang dibuat.

9. Sekop, digunakan untuk membalik dan menumpuk bahan kompos.

10. Parang, untuk memotong gulma eceng gondok.

11. Ayakan ukuran $5 \mathrm{~mm} \times 5 \mathrm{~mm}$, untuk mengayak kompos jadi (matang).

\subsection{Parameter Penelitian}

Parameter yang diamati dalam penelitian ini terdiri atas parameter utama dan parameter penunjang:
1. Parameter Utama, terdiri atas:a) Hasil akhir kompos eceng gondok yaitu volume

kompos yang jadi, dan b) Unsur hara yang terkandung di dalam kompos eceng gondok.

2. Parameter Penunjang, terdiri atas: a) Suhu kompos, b) Kelembapan kompos, dan c) Efesiensi waktu pengomposan.

\subsection{Prosedur Pelaksanaan Penelitian}

Sebelum dilakukan pengomposan, eceng gondok dipotong terlebih dahulu hingga mencapai ukuran 3-5 $\mathrm{cm}$, lalu digiling dengan menggunakan mesin penggiling kompos (Gambar 1). Setelah semua bahan-bahan kompos menjadi halus, bahan-bahan tersebut dicampur di atas terpal yang telah disediakan.

\section{Pembuatan Kompos Eceng Gondok}

Berikut ini adalah langkah- langkah pembuatan kompos eceng gondok:

a) Tahap pertama adalah pembuatan larutan gula dan EM-4. Gula putih sebanyak 17,5 g dimasukkan ke dalam larutan air $35 \mathrm{ml}$ dan EM-4 sebanyak $70 \mathrm{ml}$, kemudian diaduk hingga rata dan diamkan selama 24 jam.

b) Eceng gondok yang telah dipotong 3-5 cm digiling dengan menggunakan mesin penggiling kompos dicampur dengan kotoran hewan, arang sekam, dan dedak dengan perbandingan, 5:3:1:1 dicampur dan diaduk sampai rata. 


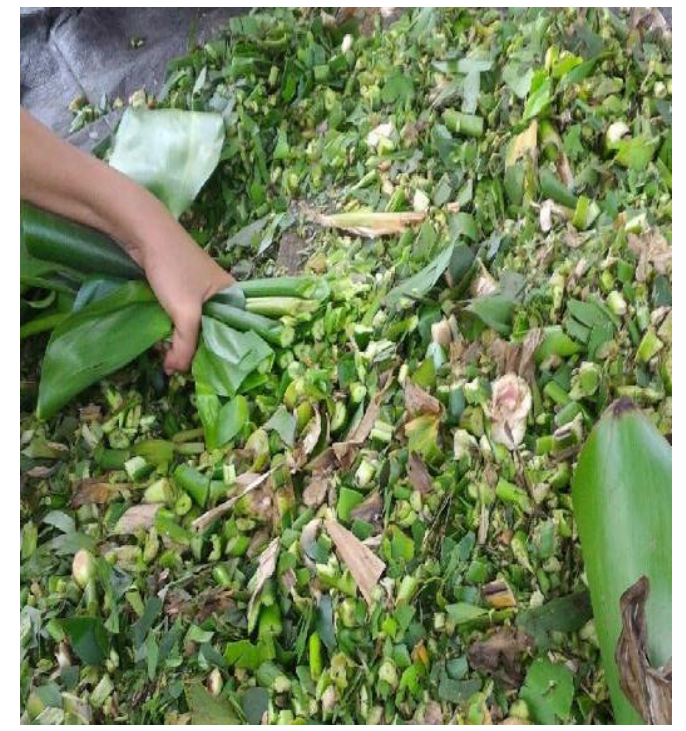

(a)

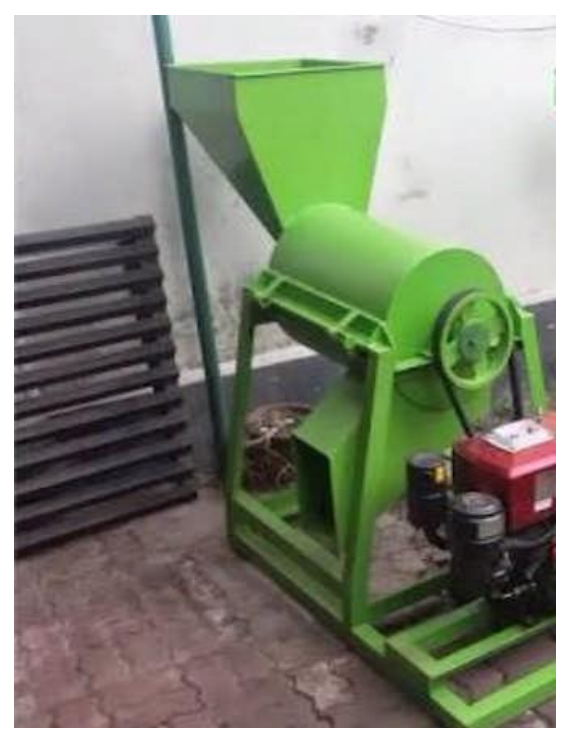

(b)

Gambar 1. (a) Proses Pencincangan Eceng Gondok ( $\pm 3-5 \mathrm{~cm})$; (b) Mesin Penggiling Bahan Kompos

c) Larutan gula dan EM-4 disiramkan secara perlahan-lahan ke dalam campuran bahan organik secara merata sampai kandungan air adonan mencapai 30-40\% ditandai dengan menggenggam adonan. Bila adonan dikepal maka air tidak menetes dan bila kepalan dilepas maka adonan masih tetap menggumpal.

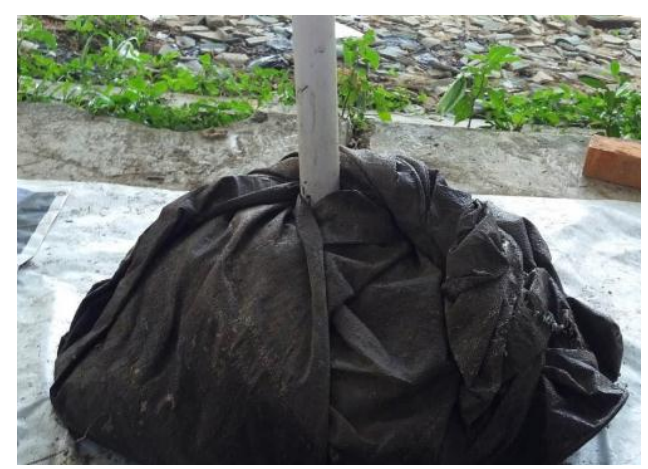

Gambar 2. Tumpukan Kompos Dengan Pipa Paralon Sebagai Sirkulasi Udara

e) Agar proses fermentasi dapat berlangsung dengan baik, suhu tumpukan kompos dijaga agar tidak melebihi $50^{\circ} \mathrm{C}$. Bila suhu lebih dari $50^{\circ} \mathrm{C}$, suhu diturunkan dengan membolak-balik tumpukan d) Bahan yang telah tercampur diletakkan di atas tempat yang kering menbentuk gundukan, kemudian diberi pipa paralon di atasnya untuk sirkulasi udara setelah itu gundukan bahan kompos ditutup dengan menggunakan terpal (Gambar 2). 
f) Setelah 21 hari bahan-bahan kompos akan terfermentasi sempurna dan siap digunakan sebagai pupuk organik.

g) Bahan yang menjadi kompos dicirikan dengan warna hitam, gembur, tidak panas, dan tidak berbau amoniak maka kompos siap digunakan sebagai pupuk organik.

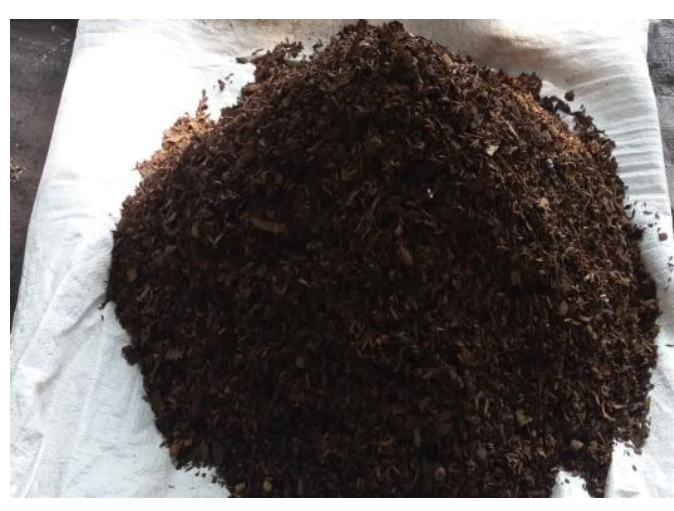

(a) h) Setelah bahan-bahan sudah jadi, maka dilakukan pengayakan. Pengayakan dilakukan untuk mendapatkan kualitas kompos yang baik (Gambar 3.a) yaitu ukuran butiran kompos yang seragam.

i) Setelah proses pengayakan selesai maka dilanjutkan dengan menimbang kompos yang sudah diayak.

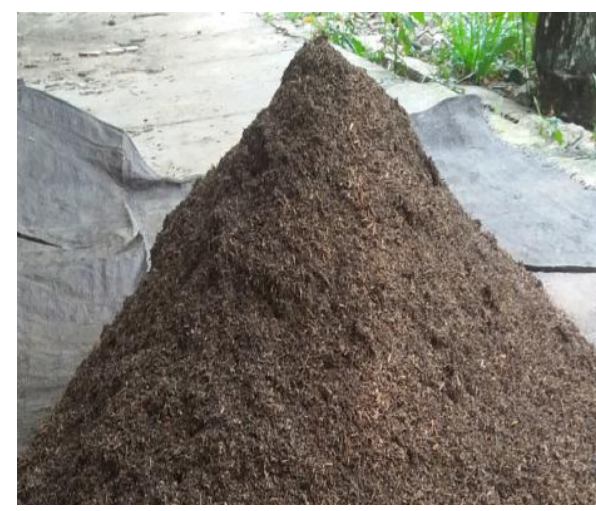

(b)

Gambar 3. (a) Hasil Pengomposan yang Sudah diayak: (b) Sisa Pengayakan (Sisa Pengomposan) Yang Belum Terurai Sempurna

\section{Pengukuran Suhu, Kelembapan dan Berat Akhir Kompos}

Pengukuran suhu dan kelembapan kompos diukur setiap hari selama berlangsungnya penelitian. Sedangkan berat akhir kompos diukur hanya sekali pada saat penelitian berakhir, dengan cara menimbang semua kompos yang telah jadi.

\section{Analisis Kandungan Hara Kompos}

Kompos yang jadi (matang) diambil sebanyak $1 \mathrm{~kg}$ untuk dijadikan sampel analisis kandungan hara. Analisis kandungan hara dilakukan di Laboratorium Tanah Fakultas Pertanian Universitas Mulawarman.

\section{Penghitungan \\ Tumpukan Kompos}

Penyusutan diukur hanya sekali pada saat penelitian berakhir, dengan cara menimbang semua kompos yang telah jadi (matang). Adapun rumus yang digunakan untuk menghitung penyusutan adalah sebagai berikut:

$$
\text { Penyusutan }=\frac{\text { Berat awal }-(\text { berat kompos jadi + sisa })}{\text { Berat awal }}
$$




\section{HASIL PENELITIAN DAN PEMBAHASAN}

Hasil pengomposan dihitung setelah proses fermentasi pada tumpukan kompos selesai. Kompos yang sudah jadi menunjukkan ciri-ciri seperti: kompos sudah berbau tanah, bertekstur halus, dan berwarna cokelat kehitaman. Kemudian dilakukan pengayakan kompos dengan menggunakan ayakan ukuran $5 \mathrm{~mm} \times 5$ mm. Pengayakan dilakukan untuk mendapatkan hasil kompos eceng gondok yang seragam.

Dari hasil pengayakan akan terlihat berapa persen kompos eceng gondok yang jadi (matang). Hasil pengayakan didapatkan hasil seperti yang terdapat pada tabel di bawah ini:

Tabel 1. Hasil Kompos Eceng Gondok Diakhir Penelitian

\begin{tabular}{cccc}
$\begin{array}{c}\text { Berat awal } \\
(\mathbf{K g})\end{array}$ & $\begin{array}{c}\text { Berat Kompos Jadi } \\
(\mathbf{K g})\end{array}$ & $\begin{array}{c}\text { Berat Kompos sisa } \\
(\mathbf{K g})\end{array}$ & $\begin{array}{c}\text { Penyusutan } \\
(\boldsymbol{\%})\end{array}$ \\
\hline $70 \mathrm{Kg}$ & $25,4 \mathrm{Kg}(36,28 \%)$ & $4 \mathrm{Kg}(5,71 \%)$ & $58 \%$ \\
\hline
\end{tabular}

Dari tabel tersebut dapat dilihat bahwa hasil kompos jadi sebanyak $25,4 \mathrm{Kg}$ $(36,28 \%)$. Hasil pengomposan menunjukkan bahwa kompos sudah berbau tanah, bertekstur halus, dan berwarna cokelat kehitaman diakhir masa pengomposan, jika dibandingkan dengan parameter SNI 2004 kompos yang dihasilkan telah matang. Kematangan kompos juga terlihat dari penyusutan berat kompos sebesar 58\% dari berat awal.

Hal ini sesuai dengan hasil penelitian Aulia (1994) dalam Fitriansyah (1997) yang menyebutkan penyusutan pada pembuatan kompos lebih dari $50 \%$. Di dalam pengomposan akan terjadi perubahan yang dilakukan oleh mikroorganisme, yaitu berupa penguraian selulosa, hemiselulosa, lemak, serta bahan lainnya menjadi karbondioksida $\left(\mathrm{CO}_{2}\right)$ dan air. Dengan adanya perubahanperubahan tersebut, maka bobot dan isi bahan dasar kompos akan menjadi berkurang antara 40-60\%, tergantung bahan dasar kompos dan proses pengomposannya (Yuwono, 2005).

Kompos matang hasil dari proses pengomposan, selanjutnya dilakukan uji kandungan $\mathrm{C}$-Organik, $\mathrm{N}$-total, $\mathrm{C} / \mathrm{N}$ rasio, $\mathrm{P}_{2} \mathrm{O}_{5}$ - tersedia, $\mathrm{K}_{2} \mathrm{O}$ - tersedia $\mathrm{CaO}, \mathrm{MgO}$ dan $\mathrm{pH}$. Sampel yang diujikan diambil sebanyak $\pm 1 \mathrm{~kg}$ sampel. Sampel ini diambil pada hari terakhir proses pengomposan (setelah selesai pengayakan dilakukan). Kondisi fisik kompos merupakan keadaan kompos yang dapat dilihat secara langsung di lapangan. Selain analisis terhadap kompos secara kimia, kondisi fisik kompos turut memberikan informasi apakah kompos tersebut telah matang atau belum. Kondisi fisik kompos matang tersebut meliputi tentang bentuk, bau dan warna kompos. Wujud visual akhir kompos matang pada penelitian ini bertekstur halus, bau dari kompos matang berbau tanah, hal ini diketahui dengan cara mendekatkan kompos tersebut ke hidung dan hasil yang didapatkan dari kompos berbau tanah, sedangkan warna kompos coklat kehitam-hitaman.

Wujud fisik kompos matang pada penelitian ini sesuai dengan pendapat Wahyono, dkk. (2003), bahwa wujud fisik kompos matang hancur dan tidak menyerupai bentuk aslinya, berbau tanah dan warna kompos gelap coklat kehitaman menyerupai tanah hutan atau pertanian.

Hasil uji kandungan kimia sampel kompos eceng gondok dan pembandingnya topsoil, tanah di bawah vegetasi alang-alang, serbuk gergaji dan 
sekam padi; dapat dilihat pada tabel di bawah ini:

Tabel 2. Hasil Analisis Unsur Hara Kompos Eceng gondok dan Beberapa Pembandingnya

\begin{tabular}{lccccc}
\hline \multicolumn{1}{c}{ Parameter } & $\begin{array}{c}\text { Kompos } \\
\text { Eceng } \\
\text { Gondok }\end{array}$ & $\begin{array}{c}\text { Serbuk } \\
\text { Gergaji }\end{array}$ & $\begin{array}{c}\text { Sekam } \\
\text { Padi }\end{array}$ & $\begin{array}{c}\text { Top soil alang- } \\
\text { alang }\end{array}$ & Standar \\
\hline $\mathrm{pH}$ & 7,82 & 6,89 & 7,08 & 5,95 & $6,80-7,49$ \\
\hline $\mathrm{C}$ - Organik (\%) & 19,29 & 37,50 & 10,53 & - & $9,80-32$ \\
\hline $\mathrm{N}$ total $(\%)$ & 2,00 & 0,67 & 1,12 & 0,32 & 0,40 \\
\hline $\begin{array}{l}\text { P2O5 Tersedia } \\
(\%)\end{array}$ & 0,58 & 1,06 & 2,78 & 0,78 & 0,20 \\
\hline $\begin{array}{l}\text { K2O Tersedia } \\
(\%)\end{array}$ & 1,87 & 0,88 & 0,86 & 1,49 & 25,50 \\
\hline CaO Total $(\%)$ & 2,35 & 0,75 & 4,07 & 2,00 & 0,60 \\
\hline MgO Total $(\%)$ & 0,39 & 0,18 & 0,27 & 0,41 & SNI 19-7030 \\
\hline \multicolumn{1}{c}{ Sumber } & Penelitian ini & Rinaldie & Rinaldie & Hardjowigeno \\
\end{tabular}

Tabel tersebut di atas memperlihatkan bahwa $\mathrm{pH}$ kompos eceng gondok sebesar 7,82 melebihi Standar Nasional Indonesia (SNI) pupuk organik. Nilai unsur $\mathrm{C}$ lebih tinggi dari standar SNI. Nilai unsur hara N-total kompos eceng gondok sebesar 2,00\% lebih tinggi daripada unsur hara pembandingnya. Hal ini disebabkan proses dekomposisi oleh mikroorganisme yang menghasilkan amoniak dan nitrogen terperangkap di dalam tumpukan kompos karena pori-pori tumpukan kompos yang sangat kecil sehingga amoniak dan nitrogen yang terlepas ke udara berada dalam jumlah yang sedikit.

Demikian juga dengan kandungan Fosfor $\left(\mathrm{P}_{2} \mathrm{O}_{5}\right)$ yang terdapat dalam kompos eceng gondok yaitu sebesar $0,582 \%$. Hal ini menunjukkan bahwa unsur hara $\mathrm{P}_{2} \mathrm{O}_{5}$ yang terdapat pada kompos lebih rendah dibandingkan dengan unsur hara topsoil lahan alangalang, serbuk gergaji dan sekam padi.
Akan tetapi kandungan $\mathrm{P}_{2} \mathrm{O}_{5}$ pada kompos eceng gondok telah memenuhi syarat SNI 2004 adalah sebesar $>0,10 \%$.

Untuk kandungan Kalium $\left(\mathrm{K}_{2} \mathrm{O}\right)$ yang terkandung dalam kompos eceng gondok sebesar $1,87 \%$ lebih tinggi dari antara semua unsur hara pembandingnya. Jika dibandingkan dengan SNI 2004, yang mensyaratkan kandungan $\mathrm{K}_{2} \mathrm{O}$ minimal yang harus ada pada kompos sebesar $>0,20 \%$, maka kandungan yang ada dalam kompos eceng gondok berada di atas standar.

Pengikat unsur kalium berasal dari hasil dekomposisi bahan organik oleh mikroorganisme dalam tumpukan bahan kompos. Bahan kompos yang merupakan bahan organik segar mengandung kalium dalam bentuk organik kompleks tidak dapat dimanfaatkan langsung oleh tanaman untuk pertumbuhannya. Akan tetapi dengan adanya aktivitas dekomposisi oleh mikroorganisme maka organik kompleks tersebut dapat diubah 
menjadi organik sederhana yang akhirnya menghasilkan unsur kalium yang dapat diserap tanaman (Widarti, dkk., 2015).

Kandungan unsur hara pada kompos eceng gondok baik untuk tanaman karena tersedia unsur hara yang relatif cukup seperti terlihat pada Tabel 2, persyaratan ini didukung oleh Gopal (1987) dalam Fitriansyah (1997), yang menyatakan bahwa kimiawi kompos eceng gondok mengandung unsur $\mathrm{N}, \mathrm{P}, \mathrm{K}$, yang termasuk unsur hara makro yang diperlukan sebagai nutrisi tanaman. Dengan kandungan unsur kimia yang tertera pada Tabel 2 maka kompos eceng gondok diharapkan baik digunakan sebagai media tanam di persemaian.

Suhu merupakan salah satu faktor terpenting dalam menentukan cepat lambatnya suatu proses pengomposan atau dekomposisi. Dari hasil pengukuran suhu terhadap tumpukan kompos eceng gondok selama penelitian ditampilkan pada Gambar 4 di bawah ini:

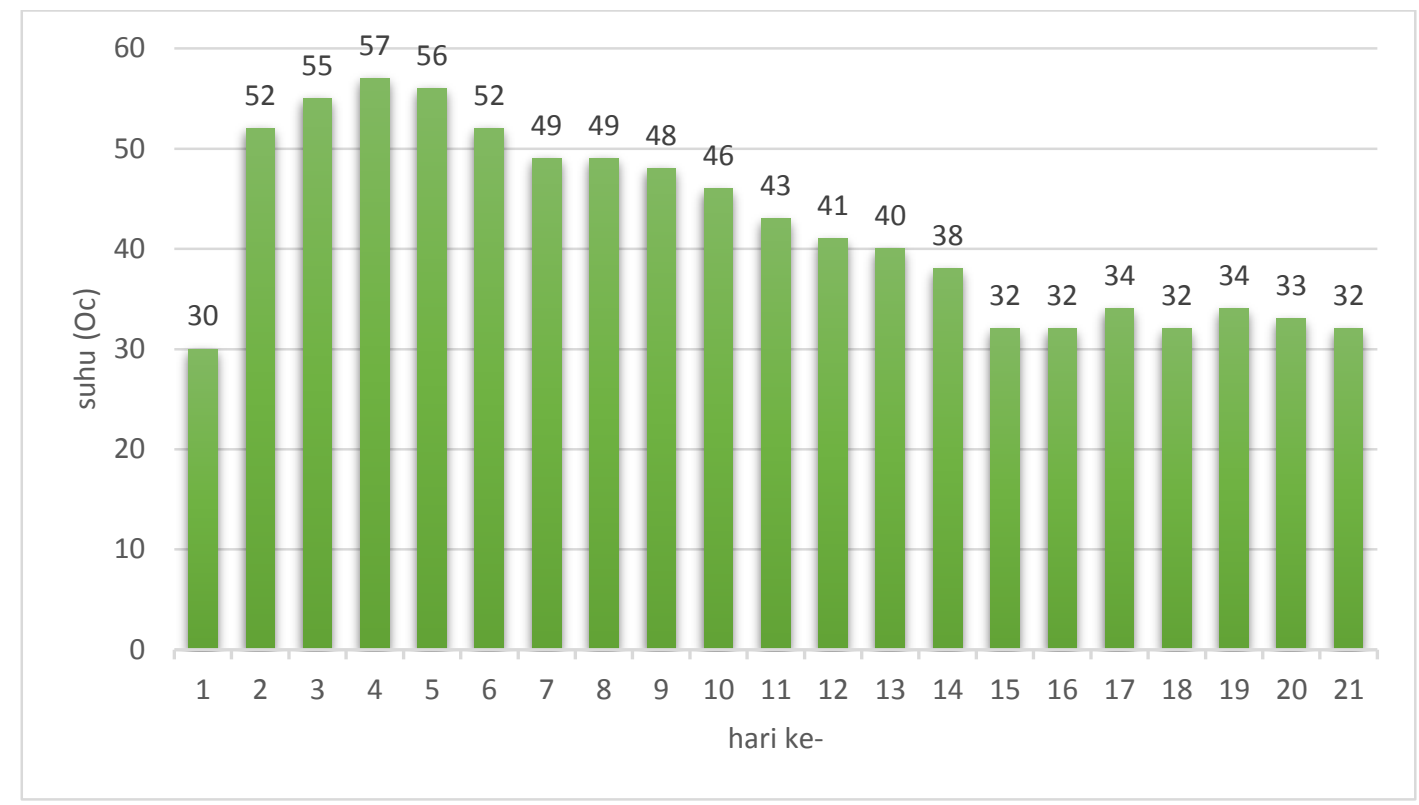

Gambar 4. Diagram Batang Suhu Tumpukan Kompos $\left({ }^{\circ} \mathrm{C}\right)$ Selama Penelitian

Dari Gambar 4 dapat dilihat bahwa rata-rata suhu yang terdapat dalam tumpukan kompos sebesar $42,1^{\circ} \mathrm{C}$ dengan suhu terendah terdapat pada hari pertama yaitu sebesar $30^{\circ} \mathrm{C}$ dan suhu tertinggi terdapat pada hari keempat yaitu sebesar $57^{\circ} \mathrm{C}$. Kompos akan lebih cepat mengalami penguraian bila suhunya tepat, suhu ideal untuk proses pengomposan adalah $30-50^{\circ} \mathrm{C}$. Kondisi suhu di atas menunjukkan suhu yang berbeda, ada yang berada pada suhu ideal dan ada pada suhu di atas ideal. Suhu yang berada di atas suhu ideal terjadi pada hari kedua sampai hari keempat. Kenaikan suhu tersebut terjadi karena adanya aktivitas mikroorganisme yang tinggi dan terjadi proses dekomposisi sehingga mengeluarkan sejumlah energi panas yang mengakibatkan suhu dalam tumpukan kompos menjadi panas.

Pengamatan suhu dilakukan untuk mengetahui perubahan aktivitas mikoorganisme karena suhu merupakan salah satu indikator dalam penguraian bahan organik. Pengamatan dilakukan pada beberapa titik dari tumpukan kompos agar memastikan kestabilan suhu kompos. Suhu yang tidak stabil serta tidak tercapainya fase termofilik $\left(40-65^{\circ} \mathrm{C}\right)$ dikarenakan tumpukan bahan yang terlalu rendah akan membuat bahan lebih cepat 
kehilangan panas, sehingga suhu yang tinggi tidak dapat tercapai. Ketinggian tumpukan kompos yang baik adalah 1 2,2 meter dan tinggi maksimum adalah 1,5 $-1,8$ meter. Suhu yang tinggi pada proses pengomposan sangat penting untuk proses higienisasi, yaitu untuk membunuh bakteri patogen dan bibit gulma, selain untuk memacu proses pengomposan karena pada umumnya proses pengomposan kombinasi suhu termofilik dan mesofilik. Kurang tingginya suhu kompos disebabkan karena jumlah limbah yang dikomposkan tidak cukup memberikan proses insulasi panas. Sejumlah energi dilepaskan dalam bentuk panas pada perombakan bahan organik sehingga mengakibatkan naik turunnya suhu.. Peningkatan suhu akibat adanya aktivitas bakteri dalam mendekomposisi bahan organik. Kondisi mesofilik lebih efektif karena aktivitas mikroorganisme didominasi protobakteri dan fungi.
Pembalikan yang dilakukan dalam proses pengomposan mengakibatakan suhu turun dan kemudian naik lagi, sehingga diperoleh suhu ideal.

Apabila suhu terlalu rendah atau pun terlalu tinggi maka bakteri yang ada pada pengomposan akan mati (Mulyono, 2014). Apabila suhu meningkat idealnya dilakukan pembalikan (pengontrolan) terhadap tumpukan kompos dengan tujuan untuk menurunkan suhu yang tinggi, sehingga dengan demikian suhu kompos akan menjadi ideal kembali.

Kelembapan memegang peranan yang sangat penting dalam proses metabolisme mikroba dan secara tidak langsung berpengaruh pada suplay oksigen. Mikroorganisme dapat memanfaatkan bahan organik apabila bahan organik tersebut larut di dalam air. Pengukuran kelembapan tumpukan kompos ditampilkan pada Gambar 5 berikut ini:

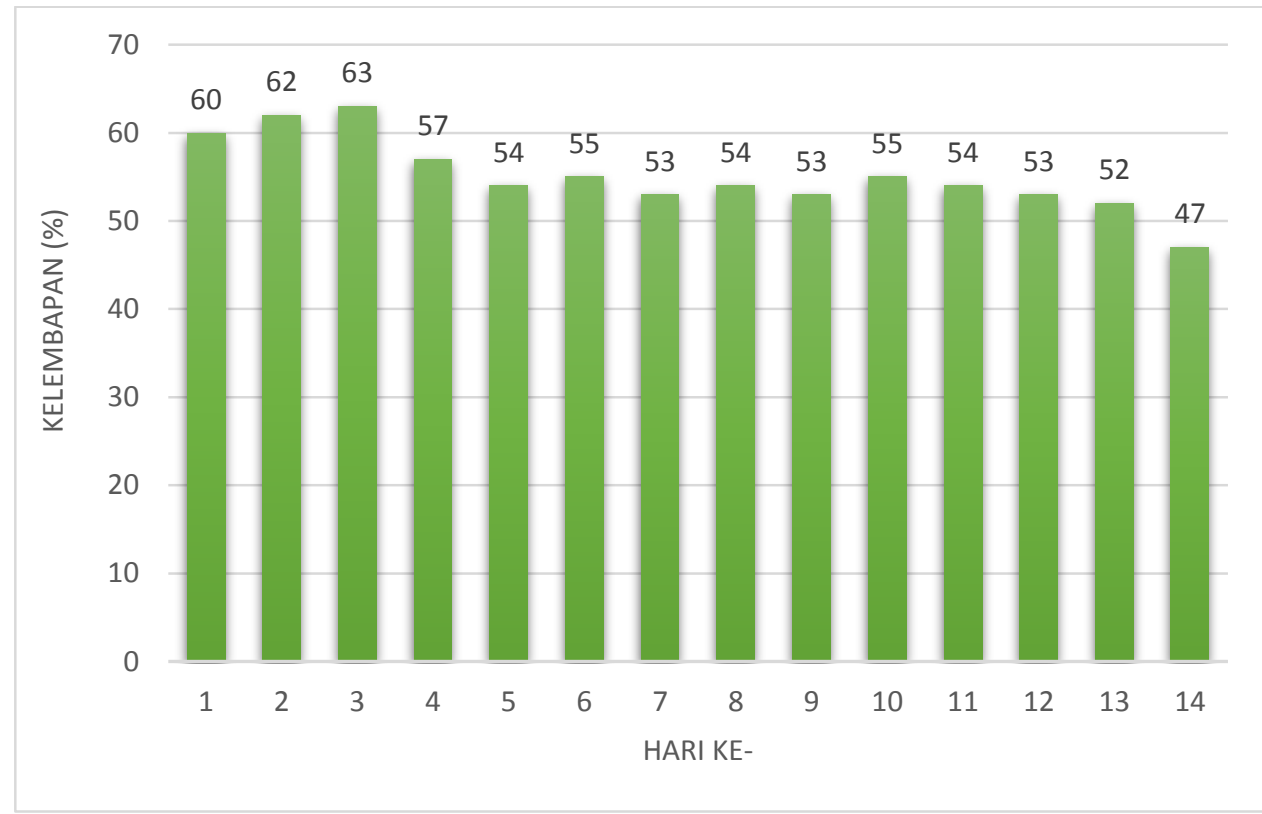

Gambar 5. Diagram Batang Kelembapan Tumpukan Kompos Eceng Gondok

Rata-rata kelembapan yang terdapat dalam tumpukan kompos sebesar 55,1\% dengan kelembapan terendah terdapat pada hari terakhir yaitu sebesar $47 \%$ dan kelembapan tertinggi terdapat pada hari ke tiga yaitu sebesar $63 \%$. Nilai kelembapan yang ditunjukkan pada gambar di atas berbeda-beda ada yang berada di atas kelembapan ideal dan ada juga yang berada di bawah kelembapan ideal. Pada 
penelitian ini dilakukan pembalikan kompos setiap hari selama 14 hari setelah pembuatan tumpukan kompos, untuk hari selanjutnya pembalikan tumpukan dilakukan jika terjadi keadaan kelembapan kompos di atas atau di bawah kelembapan ideal.

Kelembapan memegang peranan yang sangat penting dalam proses metabolisme mikroba dan secara tidak langsung berpengaruh pada suplai oksigen. Pada tahap awal pengomposan, mikroorganisma sangat aktif menyerap bahan organik, dimana hasil proses degradasi ini menghasilkan cairan (lindi). Hal ini dapat dilihat dari hasil penelitian bahwa sejak hari ke-1,2, dan 3 terjadi peningkatan kelembapan tumpukan kompos. Hal inilah yang menyebabkan kandungan air belum berkurang secara nyata pada awal pengomposan.

Sebenarnya kondisi kelembapan lebih besar dari $60 \%$ akan mencegah oksigen berpindah melalui masa sampah, sehubungan dengan porositas yang terjadi dipenuhi oleh air sehingga ruang udara bebas menjadi tidak ada, sehingga kondisi menjadi anaerobik. Kondisi ini akan menyebabkan proses pengomposan berlangsung lebih lama. Di sisi lain, jika kelembapan terlalu rendah, efisiensi degradasi akan menurun karena kurangnya air untuk melarutkan bahan organik yang akan didegradasi oleh mikroorganisma sebagai sumber energinya (Pandebesie dan Rayuanti, 2013).

Menurut Mulyono (2014), kelembapan 40-60\% adalah kisaran optimum untuk metabolisme mikroba. Apabila kelembapan di bawah 40\%, aktivitas mikroba akan mengalami penurunan dan akan lebih rendah lagi pada kelembapan $15 \%$ akan tetapi dapat diatasi dengan menambahkan air pada tumpukan kompos, Apabila kelembapan lebih besar dari $60 \%$, hara akan tercuci, volume udara berkurang, akibatnya aktivitas mikroba akan menurun dan akan terjadi fermentasi anaerobik yang menimbulkan bau tidak sedap, maka perlu dilakukan pembalikan tumpukan kompos agar kelembapan kompos menjadi ideal (40-60\%).

Apabila kelembapan kompos berada di atas kelembapan ideal (40-60\%), maka mikroorganisme di dalam tumpukan kompos tidak dapat hidup dengan baik sehingga suhu tumpukan kompos tidak dapat mencapai suhu minimal pengomposan aerob $40^{\circ} \mathrm{C}$. Yuwono (2009) menyatakan bahwa bahan air (kelembapan) yang dianjurkan dalam pengomposan aerob adalah 40-50\%. Apabila terlalu banyak air dalam tumpukan kompos bisa berakibat bahan kompos tersebut semakin padat, melumerkan sumber makanan yang dibutuhkan oleh mikroba, dan memblokir mikroba yang masuk.

Beberapa cara sederhana untuk mengukur kelembapan bahan baku kompos yaitu dengan mengambil segenggam bahan baku kompos dari dalam tumpukan kompos dan kemudian diperas (digenggam) sehingga terlihat kondisi sebagai berikut:

a) Apabila air tidak ada keluar, atau tangan tidak basah, maka ini berarti tumpukan kompos terlalu kering atau kelembapannya kurang dari $40 \%$.

b) Apabila air keluar sedikit, satu atau dua tetes, tangan menjadi basah, maka ini berarti kelembapan sekitar 50-60\%.

c) Apabila belum diperas sudah keluar air lebih dari dua tetes, maka ini berarti tumpukan kompos terlalu basah (> $60 \%$ ).

Untuk menguji kelembapan, kompos diambil dari bagian dalam tumpukan kompos karena bagian luar tumpukan kompos cenderung lebih kering.

Tumpukan kompos eceng gondok pada penelitian ini, pada tiga hari pertama setelah penumpukan kompos mengalami kelembapan di atas rata-rata (> 60\%), 
namun pada hari selanjutnya sampai akhir penelitian kelembapan tumpukan berada pada kelembapan ideal (40-60\%). Hal ini sesuai dengan pernyataan Aulia (1994) dalam Fitriansyah (1997) yang menyatakan, bahwa kisaran kelembapan ideal adalah (40-60\%), dengan tingkat terbaik sekitar $50 \%$. Kisaran $50 \%$ harus dipertahankan untuk memperoleh jumlah populasi mikroorganisme yang terbesar, yang mana pada kelembapan ideal tersebut mikroorganisme dapat hidup, tumbuh dan berkembang dengan baik.

Waktu pembuatan kompos eceng gondok dengan metode semi anaerob menggunakan aktivator EM4 memerlukan waktu selama 21 hari untuk mendapatkan kompos jadi (matang). Sedangkan pembuatan kompos eceng gondok dengan metode aerob tidak menggunakan aktivator EM4 yang dilakukan oleh Fitriansyah (1997), dengan perlakuan dipotong 3-5 cm, tidak ditiriskan sebelum pengomposan (perlakuan A) dan perlakuan dipotong 3-5 $\mathrm{cm}$ dan ditiriskan 3 hari sebelum pengomposan (perlakuan B) serta perlakuan dipotong $3-5 \mathrm{~cm}$ dan ditiriskan 6 hari sebelum pengomposan (perlakuan C) memerlukan waktu selama 30 hari. Sehingga waktu pengomposan metode semi anaerob menggunakan EM4 lebih cepat dibandingkan dengan metode aerob tanpa menggunakan EM4. Perbandingan antara pengomposan menggunakan EM4 dan tidak menggunakan EM4 ditampilkan pada Tabel 3.

Tabel 3. Perbandingan Kompos Eceng Gondok Menggunakan Metode Semi Anaerob Dengan Penambahan Aktivator EM4 dan Kompos Eceng Gondok Dengan Metode Aerob Tanpa Aktivator

\begin{tabular}{|c|c|c|c|c|}
\hline \multirow{2}{*}{ Parameter } & \multirow{2}{*}{ Penelitian ini } & \multicolumn{3}{|c|}{ Fitriansyah (1997) } \\
\hline & & $\mathbf{A}$ & B & $\mathbf{C}$ \\
\hline Efisiensi waktu (hari) & 21 & 30 & 30 & 30 \\
\hline Penyusutan (\%) & 58 & 60,60 & 47 & 47,26 \\
\hline Metode & Semi Anarob & & erob & \\
\hline Aktivator & Dengan Aktivator & & Akti & \\
\hline
\end{tabular}

Tabel tersebut di atas memperlihatkan bahwa waktu yang diperlukan pada metode semi anaerob dengan menggunakan EM4 (penelitian ini) lebih efisien dibandingkan dengan penelitian yang dilakukan oleh Fitriansyah (1997). Dalam hal proses penyusutan tumpukan kompos eceng gondok pada perlakuan dipotong $3-5 \mathrm{~cm}$, tidak ditiriskan sebelum pengomposan (perlakuan A) penyusutan yang terjadi lebih tinggi $(60,60 \%)$ bila dibandingkan dengan penelitian ini (58\%). Perlakuan dipotong $3-5 \mathrm{~cm}$ dan ditiriskan 3 hari sebelum pengomposan (perlakuan B) penyusutan lebih rendah. Demikian juga pada perlakuan dipotong $3-5 \mathrm{~cm}$ dan ditiriskan 6 hari sebelum pengomposan (perlakuan C) penyusutannya lebih rendah dari perlakuan tanpa dipotong dengan metode semi anaerob menggunakan EM4 (penelitian ini). Hal ini karena pada penelitian ini tumbuhan eceng gondok tidak ditiriskan sehingga penyusutan pada tumpukan kompos lebih dari 50\%. 


\section{KESIMPULAN}

Kesimpulan dari penelitian pengomposan ini adalah bahwa Eceng gondok dapat dimanfaatkan sebagai alternatif pembuatan kompos untuk media tumbuh tanaman di persemaian. Hasil analisis kimia kompos eceng gondok (Corganik $=19,29 \%, \mathrm{~N}$-total $=2,00 \%, \mathrm{C} / \mathrm{N}$ rasio $=9,63 \%$, P-total $=0,582 \%, \mathrm{~K}$-total $=$ $1,871 \%, \mathrm{CaO}=2,358 \%, \mathrm{MgO}=0,390 \%$,) dan fisik (bentuk, bau dan warna) kompos secara keseluruhan telah memenuhi standar kualitas kompos matang berdasarkan SNI 19-7030-2004. Pembuatan kompos eceng gondok dengan metode semi anaerob menggunakan larutan aktivator EM4 memerlukan waktu selama 21 hari. Penyusutan kompos berbahan baku eceng gondok hingga menjadi kompos siap pakai adalah 58\%.

\section{DAFTAR PUSTAKA}

Fitriansyah, F. (1997). Percobaan Pembuatan Kompos Dari Eceng Gondok Dengan Metode Aerob Untuk Media Tanaman Di Persemaian. Skripsi. Fakultas Kehutanan. Universitas Mulawarman. Samarinda.

Hajama, N. (2014). Studi Pemanfaatan Eceng Gondok Sebagai Bahan Baku Pupuk Kompos Dengan Menggunakan Aktivator EM4 Dan Mol Serta Prospek Pengembangannya. Jurnal Fakultas Teknik. Universitas Hasanuddin. Makassar.

Mulyono. (2014). Membuat MOL Dan Kompos Dari Sampah Rumah Tangga. Jakarta: Agromedia pustaka.

Murbandono, L. (2003). Membuat Kompos. Jakarta: Penebar Swadaya.

Rinaldie, I. (2011). Percobaan Pembuatan Kompos Dengan Metode Semi
Anaerob Dari Tiga Bahan Utama Yang Berbeda. Skripsi. Fakultas Kehutanan. Universitas Mulawarman. Samarinda.

Pandebesie, E. S., \& Rayuanti, D. (2013). Pengaruh penambahan sekam pada proses pengomposan sampah domestik. Jurnal Lingkungan Tropis, 6(1), 31-40.

Samekto R. (2006). Pupuk Kompos. Klaten: PT Intan Sejati.

Setyaningsih L. (2007). Pemanfaatan cendawan micoriza arbuskula dan kompos aktif untuk meningkatkan pertumbuhan semai mindi (Melia azedarach Linn) pada media tailing tambang emas Pongkor [tesis]. Bogor: Sekolah Pascasarjana, Institut Pertanian Bogor.

Sittadewi, H. (2007). Pengolahan Bahan Organik Eceng Gondok Menjadi Media Tumbuh Untuk Mendukung Pertanian Organik. Jurnal. Badan Pengkajian dan Penerapan Teknologi. Jakarta.

Subroto. H., dan A. Yusrani., (2005). Kesuburan dan Pemanfaatan Tanah. Edisi Pertama. Malang: Bayumedia Publising.

Suriany, A. (2007). Pengaruh Penambahan Kompos Terhadap Perubahan Sifat Tanah Dan Pertumbuhan Tanaman. Fakultas Pertanian, Universitas Tanjungpura, Pontianak.

Wahyono, S., F. Sahwan dan F. Suryanto., (2003). Mengolah Sampah Menjadi Kompos. Edisi Pertama. Jakarta.

Widarti, B. N., Wardhini, W. K., \& Sarwono, E. (2015). Pengaruh rasio $\mathrm{C} / \mathrm{N}$ bahan baku pada pembuatan kompos dari kubis dan kulit pisang. Jurnal Integrasi Proses, 5(2). 
Widyaningsih, T. S. (2007). Penyerapan logam $\mathrm{Cr}$ total dan logam $\mathrm{Cu} 2+$ dengan eceng gondok pada sistem air mengalir (Doctoral dissertation, Universitas Gadjah Mada).

Yuliarti, N. (2009). 1001 Cara Menghasilkan Pupuk Organik. Yogyakarta.
Yuwono, D. (2005). Kompos dengan Cara Aerob Maupun Anaerob, Untuk Menghasilkan Kompos Berkualitas. Jakarta: Penebar Swadaya. 